\title{
Meningitis and stridor in advanced Human immunodeficiency virus/acquired immune deficiency syndrome
}

This article was published in the following Dove Press journal:

International Journal of General Medicine

12 September 2013

Number of times this article has been viewed

\section{P Naidoo \\ D Pillay \\ S Saman}

Department of Internal Medicine, Port Shepstone Regional Hospital, University of KwaZulu-Natal, South Africa
Correspondence: P Naidoo

Department of Internal Medicine, Port Shepstone Regional Hospital, University of KwaZulu-Natal, Private Bag X3032, Ranburg, 2125, South Africa

Email poobalan Inaidoo@yahoo.com
Abstract: A 37-year-old female presented confused with a preceding history of severe headache. After clinical examination and investigations, she was diagnosed with disseminated tuberculosis (including central nervous system involvement), and Human immunodeficiency virus/acquired immune deficiency syndrome. Her hospital stay was complicated. She developed stridor and a cerebrovascular accident with left hemiplegia. She died approximately 2 weeks after admission. The potential causes of her stridor included a mediastinal mass or a central mechanism secondary to tuberculosis meningitis. Limited resources precluded definitive imaging of the chest to rule out a mediastinal mass. Further, an autopsy was not done. Despite these limitations, this case is unique because it reports the presence of both stridor and tuberculosis meningitis in an adult patient.

Keywords: Human immunodeficiency virus, acquired immune deficiency syndrome, meningitis, stridor, tuberculosis

\section{Case report}

A 37-year-old female with retroviral disease was brought to casualty by caregivers because she was confused. The confusion was preceded by severe headache for 3 weeks. She had no history of vomiting or neck stiffness. She had started antiretroviral drugs 2 months earlier and subsequently defaulted.

On initial clinical examination, the patient was confused (not orientated to time, place, or person), pyrexial, and pale. She was normotensive $(108 / 80 \mathrm{mmHg})$ but had a tachycardia of 107 beats per minute. The cardiac examination was otherwise normal. She was tachypneic with a respiratory rate of 22 breaths per minute and crackles throughout both lung fields. Neurologic examination identified neck stiffness without localizing signs.

Blood tests, microbiology, lumbar puncture analysis, and a chest film were done (Tables 1-6 and Figure 1). The patient had normocytic normochromic anemia, hyponatremia, and a slightly raised alanine transaminase. Her viral load was raised $(678,233$ copies $/ \mathrm{mL})$ and her CD4 count was low $\left(155.28 \times 10^{6} / \mathrm{L}\right)$. Cerebrospinal fluid analysis showed an increase in lymphocytes, a raised protein level, and decreased glucose (Table 4). India ink staining and a Cryptococcus latex antigen test were both negative (Table 4). Sputum analysis and blood cultures were negative for Mycobacteria (Table 7).

The anterior-posterior supine chest film with the patient rotated to the right (Figure 1) showed bilateral nodular infiltrates with hilar and mediastinal lymphadenopathy 
Table I Full blood count

\begin{tabular}{|c|c|c|c|c|c|c|}
\hline & $\begin{array}{l}\text { Laboratory } \\
\text { reference range }\end{array}$ & Day 0 & Day 2 & Day 7 & Day I I & Day 16 \\
\hline White cell count $\left(\times 10^{9}\right.$ cells/L) & $4.00-10.00$ & 7.00 & 7.60 & 9.90 & 5.50 & 6.70 \\
\hline Red cell count $\left(\times 10^{12}\right.$ cells/L) & $3.80-4.80$ & 2.84 & 3.53 & 2.86 & 3.25 & 3.50 \\
\hline Hemoglobin (g/dL) & $12.0-15.0$ & 8.7 & 10.5 & 8.7 & 10.0 & 10.8 \\
\hline Hematocrit (L/L) & $0.360-0.460$ & 0.260 & 0.330 & 0.263 & 0.300 & 0.323 \\
\hline Mean cell volume (fL) & $83.0-101.0$ & 91.8 & 93.7 & 92.2 & 92.2 & 92.4 \\
\hline Mean cell hemoglobin (pg) & $27.0-32.0$ & 30.5 & 29.8 & 30.6 & 30.6 & 30.8 \\
\hline Mean cell hemoglobin concentration $(\mathrm{g} / \mathrm{dL})$ & $31.5-34.5$ & 33.3 & 31.8 & 33.2 & 33.2 & 33.3 \\
\hline Red cell distribution width (\%) & $11.6-14.0$ & 22.6 & 22.0 & 22.7 & 22.9 & 19.6 \\
\hline Platelet count $\left(\times 10^{9}\right.$ cells $\left./ \mathrm{L}\right)$ & $150-400$ & 236 & 264 & 228 & 292 & 176 \\
\hline Mean platelet volume (fL) & $7.0-11.4$ & 7.8 & 8.3 & 7.4 & 7.1 & 7.4 \\
\hline International normalized ratio (second/second) & $0.8-1.2$ & & 1.00 & 1.23 & 0.92 & 1.02 \\
\hline Prothrombin time (second) & $12.0-13.0$ & & 10.8 & 13.3 & 9.9 & $1 \mathrm{I} .0$ \\
\hline
\end{tabular}

not excluded. A veiling pleural effusion was noted on the left, and the left cardiac border was obscured by confluent opacification in the lingular segment of the left upper lobe.

The patient was initially assessed as having disseminated tuberculosis with central nervous system involvement, specifically meningitis. She was admitted to the medical ward and started on antituberculosis therapy, glucocorticosteroids, and supportive care.

On day 2, the patient developed both inspiratory and expiratory stridor and her initial respiratory distress worsened, with the respiratory rate increasing to 46 breaths per minute. The patient was started on adrenalin nebulization. The patient was intubated in theater and then transferred to the high care ward with a T-piece attached to the endotracheal tube. The glottis appeared normal during endotracheal intubation. At this point she was normotensive $(113 / 73 \mathrm{mmHg})$, tachycardiac ( 152 beats per minute), and tachypneic ( 54 breaths per minute). Her oxygen saturation was $94 \%$ on $40 \%$ oxygen via a T-piece. A computed tomography (CT) scan of her brain and chest were requested. Unfortunately, the CT scanner at the base hospital was not working and the patient was deemed too unstable for transport to a CT scanner 2 hours away.
High-dose cotrimoxazole, piperacillin/tazobactam, and amikacin were initiated. The patient remained pyrexial with a temperature of $38^{\circ} \mathrm{C}$.

On day 4 , the patient's oxygen saturation dropped to $92 \%$ and her arterial oxygen was $59 \mathrm{mmHg}$ on $40 \%$ oxygen. Her chest film suggested a left-sided pleural effusion. Her blood pressure was also decreasing and central venous pressure was low $\left(0 \mathrm{~cm} \mathrm{H}_{2} \mathrm{O}\right)$. The central venous pressure was optimized and inotropic cardiac support was initiated. The patient's level of consciousness improved.

On day 7 , she developed worsening hepatic impairment so her treatment was changed to a "liver-friendly" tuberculosis regimen. Clinical improvement was noted (improved level of consciousness, pulse 104 per minute, blood pressure $94 / 68 \mathrm{mmHg}$, oxygen saturation $100 \%$ on $60 \%$ T-piece oxygen, central venous pressure $8 \mathrm{~cm} \mathrm{H}_{2} \mathrm{O}$, respiratory rate 36 breaths per minute) and it was decided to taper her inotropic support.

On day 12, the patient extubated herself. Her vitals at this point were as follows: pulse 102 per minute, oxygen saturation $98 \%$ on $40 \%$ face mask oxygen, respiratory rate 30 breaths minute, and blood pressure $147 / 71 \mathrm{mmHg}$. Vesicular lesions

Table 2 Urea and electrolytes

\begin{tabular}{|c|c|c|c|c|c|c|}
\hline & $\begin{array}{l}\text { Laboratory } \\
\text { reference range }\end{array}$ & Day 0 & Day 2 & Day 7 & Day I I & Day 16 \\
\hline Sodium $(\mathrm{mmol} / \mathrm{L})$ & $136-145$ & 125 & 132 & 120 & 133 & 128 \\
\hline Potassium (mmol/L) & $3.5-5.1$ & 4.6 & 3.8 & 3.9 & 4.9 & 3.2 \\
\hline Chloride (mmol/L) & $98-107$ & 90 & 92 & 84 & 101 & 98 \\
\hline Bicarbonate $(\mathrm{mmol} / \mathrm{L})$ & $23-29$ & 24 & 25 & 23 & 24 & 24 \\
\hline Anion gap (mmol/L) & $9-16$ & 16 & 19 & 17 & 13 & 9 \\
\hline Urea (mmol/L) & $2.1-7.1$ & 2.7 & 4.7 & 3.4 & 2.9 & 1.9 \\
\hline Creatinine $(\mu \mathrm{mol} / \mathrm{L})$ & $49-90$ & 49 & 47 & 37 & 34 & 37 \\
\hline $\begin{array}{l}\text { Estimated glomerular filtration } \\
\text { rate (MDRD formula) }\left(\mathrm{mL} / \mathrm{min} / 1.73 \mathrm{~m}^{2}\right)\end{array}$ & $>60$ & $>60$ & $>60$ & $>60$ & $>60$ & $>60$ \\
\hline
\end{tabular}

Abbreviation: MDRD, Modification of Diet in Renal Disease. 
Table 3 Liver function tests

\begin{tabular}{lllllll}
\hline & $\begin{array}{l}\text { Laboratory } \\
\text { reference range }\end{array}$ & Day 0 & Day 2 & Day 7 & Day II & Day I6 \\
\hline Total protein $(g / L)$ & $60-78$ & 78 & 72 & 64 & 70 & 59 \\
Albumin $(g / L)$ & $35-52$ & 25 & 23 & 20 & 21 & 19 \\
Total bilirubin $(\mu \mathrm{mol} / \mathrm{L})$ & $5-21$ & 7 & 9 & 16 & 6 & 12 \\
Alanine transaminase $(\mathrm{U} / \mathrm{L})$ & $7-35$ & 43 & 55 & 34 & 126 & 151 \\
Alkaline phosphatase $(\mathrm{U} / \mathrm{L})$ & $42-98$ & 112 & 103 & 109 & 190 & 172 \\
Gamma-glutamyl transferase $(\mathrm{U} / \mathrm{L})$ & $0-35$ & 113 & $1 \mathrm{II}$ & 144 & 303 & 234 \\
C-reactive protein $(\mathrm{mg} / \mathrm{L})$ & $0-5$ & & & $>200$ & & 104 \\
\hline
\end{tabular}

with a dermatomal distribution were noted on her buttock and the patient developed diarrhea. The endotracheal tube and stool were sent for microbiologic analysis (Table 7). Approximately 9 hours later, the patient desaturated and was reintubated. The patient then underwent a tracheostomy.

The following day she suffered a cerebrovascular accident with left hemiplegia. The patient died later that day, approximately 2 weeks after admission.

\section{Discussion}

The combination of tuberculosis meningitis and stridor has not been reported previously. In our index patient, there are two possible causes for her stridor. One possibility is a mediastinal mass and the other is a central mechanism. This discussion will focus on the central mechanism of stridor. During laryngoscopy and intubation, the patient's glottis was macroscopically normal and she was intubated without difficulty. The chest film did not show obvious mediastinal enlargement. However, one cannot rule out a mediastinal mass as a possible cause of stridor. The chest film was an

Table 4 Cerebrospinal fluid analysis

\begin{tabular}{|c|c|c|}
\hline & $\begin{array}{l}\text { Laboratory } \\
\text { reference } \\
\text { range }\end{array}$ & Day 0 \\
\hline Clarity & & Clear \\
\hline Color before centrifugation & & Colorless \\
\hline CSF glucose* (mmol/L) & & 1.2 \\
\hline CSF chloride (mmol/L) & $118-132$ & 106 \\
\hline CSF protein $(g / L)$ & $0.15-0.45$ & 1.37 \\
\hline Polymorphonuclear cells (cells/ $\mu \mathrm{L}$ ) & 0 & 0 \\
\hline Lymphocytes (cells/uL) & 0 & 32 \\
\hline Erythrocytes (cells/uL) & 0 & 0 \\
\hline Unidentified cells (cells/ $\mu \mathrm{L}$ ) & 0 & 0 \\
\hline India ink stain & & $\begin{array}{l}\text { Encapsulated yeasts } \\
\text { not observed }\end{array}$ \\
\hline $\begin{array}{l}\text { Cryptococcus latex } \\
\text { antigen test }\end{array}$ & & Negative \\
\hline
\end{tabular}

Notes: ${ }^{*}$ CSF glucose is normally $60 \%-80 \%$ of plasma glucose in samples taken within 15 minutes of each other. Random blood glucose was $5.8 \mathrm{mmol} / \mathrm{L}$ for this patient just before lumbar puncture was done.

Abbreviation: CSF, cerebrospinal fluid. anterior-posterior supine view (limiting interpretation) and not sensitive enough to rule out a mediastinal mass. Ideally, a CT scan or magnetic resonance imaging should have been done. These aforementioned imaging modalities would have assisted in ruling out a mediastinal mass as a cause of stridor.

The cerebrospinal analysis (elevated lymphocytes and protein) suggested tuberculosis meningitis. We hypothesized that tuberculosis meningitis may have resulted in stridor via a central mechanism. In South Africa, tuberculosis meningitis is a common central nervous system form of tuberculosis. The cerebrospinal fluid analysis typically shows increased protein and lymphocytes. Currently, diagnostic tests (including polymerase chain reaction) are not sensitive enough to detect tuberculosis meningitis ${ }^{1}$ and these patients are empirically initiated on antituberculosis combination therapy and corticosteroids.

Tuberculosis is a major cause of mortality and morbidity.,3 Tuberculosis manifestations are protean and affect all systems of the body. ${ }^{4}$ Tuberculosis may cause stridor, either by direct laryngeal involvement ${ }^{5}$ or indirectly by causing a mediastinal mass. ${ }^{6,7}$

The academic literature does not report a case of tuberculosis meningitis causing stridor. However, there have been reports in children whereby raised intracranial pressure, hydrocephalus, and Arnold Chiari malformation have resulted in stridor. ${ }^{8-10}$

Stritzke et $\mathrm{al}^{8}$ reported a case of congenital stridor associated with a low lumbar neural tube defect and Chiari malformation. The authors proposed that the granulomatous meningitis reaction to vernix caseosa may have played a role in the central mechanism for stridor. The most popular hypothesis to explain the mechanism of stridor in

Table 5 Molecular investigations for HIV

\begin{tabular}{ll}
\hline HIV viral load (copies/mL) & Day 0 \\
\hline
\end{tabular}

Abbreviation: HIV, Human immunodeficiency virus. 
Table 6 Absolute CD4 count

\begin{tabular}{llll}
\hline & & Day 0 & Day 7 \\
\hline Absolute CD4 count $\left(\times 10^{6}\right.$ cells/L) & $500.00-2,010.00$ & 155.28 & 26 \\
\hline
\end{tabular}

Chiari malformation is that brain stem compression and cerebrospinal fluid obstruction secondary to hind brain herniation "[...]results in parenchymal dysplasia, scarring, and adhesions that might clinically result in stridor". ${ }^{11}$ This hypothesis is vague but serves as a starting point for investigation into the actual mechanism by which granulomatous meningitis results in stridor.

Correa-Restrep et $a l^{10}$ reported a case of vernix caseosa meningitis and laryngeal stridor in an infant with myelomeningocele. They suggested that chemical meningitis involving the cranial nerves might account for the laryngeal stridor. They do not describe exactly how cranial nerve involvement results in laryngeal stridor.

In our index patient, complicated tuberculosis meningitis resulted in a cerebrovascular accident with left hemiplegia, probably secondary to arteritis of cerebral vessels. ${ }^{3,12}$ It is probable that she also developed a hydrocephalus with raised intracranial pressure as a complication of meningitis. Hydrocephalus is a known complication of tuberculosis meningitis, ${ }^{13}$ with ventricular enlargement present in most patients. ${ }^{3}$ Hydrocephalus may be secondary to obstruction of the basal cisterns, outflow of the fourth ventricle, or occlusion of the cerebral aqueduct. ${ }^{3}$

Anderson et $\mathrm{al}{ }^{13} \mathrm{did}$ a retrospective review of 104 patients with tuberculosis meningitis. They reported that complications occurred in 81 (78\%) of patients. Hydrocephalus was the second most common complication (42\%) and stroke (33\%) the third, with hyponatremia being the most common complication (49\%). We postulate that the central mechanism

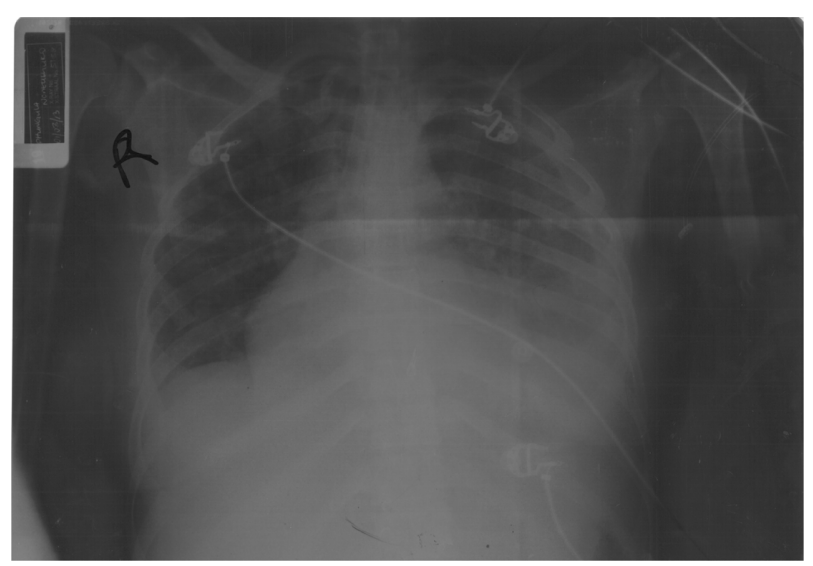

Figure I Anterior-posterior supine chest film.
Table 7 Microbiology

\author{
Stool analysis \\ Appearance: watery \\ Leucocytes: not observed \\ Erythrocytes: not observed \\ Yeasts: Scanty (I+) \\ Parasite(s): not observed \\ Salmonella species: not isolated \\ Shigella species: not observed \\ Tracheal aspirate culture \\ Moderate growth of Klebsiella pneumoniae \\ Blood culture \\ No growth after 6 weeks \\ Sputum analysis \\ Auramine stain for acid-fast bacilli negative \\ Polymerase chain reaction for Mycobacteria tuberculosis negative
}

for stridor may be multifactorial, including raised intracranial pressure, hydrocephalus, and basilar involvement.

The exact mechanism by which central mechanisms result in stridor remains to be elucidated. It is interesting that, of all the patients who develop hydrocephalus secondary to tuberculosis meningitis, there are no reports of these patients developing stridor. We are unable to explain why our patient developed stridor whereas previous patients with tuberculous meningitis did not develop stridor despite hydrocephalus and raised intracranial pressure. Perhaps the severity of the hydrocephalus and degree of intracranial hypertension were contributory factors to our patient developing stridor. It is also possible that unknown genetic factors may have contributed. In addition, our patient's stridor may have been secondary to direct obstruction of the airway, eg, by mediastinal lymphadenopathy.

Unfortunately limited resources precluded definitive imaging studies and an autopsy. These may have added invaluable information for understanding the cause and mechanism of stridor, be it secondary to a mediastinal mass or a central mechanism.

\section{Acknowledgment}

We thank Dr MA Ndlovu, specialist radiologist, Department of Radiology, Port Shepstone Regional Hospital, for reporting the chest film. We also thank Sue Thomas, Sylvia Barker, and Kevin Ho, Medical Affairs, Boehringer-Ingelheim, South Africa, for assisting with acquisition of reference articles.

\section{Disclosure}

The authors report receiving no support from any organization in relation to this work and having no financial relationships with any organizations that might have an 
interest in the submitted work in the previous 3 years nor other relationships or activities that could appear to have influenced this work.

\section{References}

1. Thwaites GE. Advances in the diagnosis and treatment of tuberculous meningitis. Curr Opin Neurol. 2013;26:295-300.

2. Lademarco MF, Castro KG. Epidemiology of tuberculosis. Semin Respir Infect. 2003;18:225-240.

3. Garg RK. Classic diseases revisited: tuberculosis of the central nervous system. Postgrad Med J. 1999;75:133-140.

4. Zumla A, Raviglione M, Hafner R, von Reyn CF. Tuberculosis. N Engl J Med. 2013:368:745-755.

5. Ramadan HH, Wax MK. Laryngeal tuberculosis. A cause of stridor in children. Arch Otolaryngol Head Neck Surg. 1995;121:109-112.

6. Hodder RV, Le Saux N, Shamji FM, Kronick SH. Tuberculosis presenting as stridor. Ann Thorac Surg. 1987;43:98-99.

7. De Ugarte DA, Shapiro NL, Williams HL. Tuberculous mediastinal mass presenting with stridor in a 3 month old child. J Pediatr Surg. 2003;38:624-625.
8. Stritzke AL, Dunham CP, Smyth JA, Steinbok P. Congenital stridor in the context of Chiari malformation type 2: the etiological role of vernix caseosa granulomatous meningitis. J Neurosurg Pediatr. 2011;8:372-376.

9. Prabhakar H, Aji Z, Rath GP. Recurrent stridor due to raised intracranial pressure after meningitic hydrocephalus. J Neurosurg Anesthesiol. 2007;19:66-67.

10. Correa-Restrep A, Robertson C, Rozdilsky B. Vernix caseoasa meningitis and laryngeal stridor in an infant with myelomeningocele. J Neurosurg. 1975;42:718-722.

11. Yamada H, Tanak Y, Nakamura S. Laryngeal stridor associated with the Chiari II malformation. Childs Nerv Syst. 1985;1:312-318.

12. Misra UK, Kalita J, Maurya PK. Stroke in tuberculosis meningitis. J Neurol Sci. 2011;303:22-30.

13. Anderson NE, Somaratne J, Mason DF, Holland D, Thomas MG. Neurological and systemic complications of tuberculosis meningitis and its treatment at Auckland City Hospital, New Zealand. J Clin Neurosci. 2010;17:1114-1118.
International Journal of General Medicine

\section{Publish your work in this journal}

The International Journal of General Medicine is an international, peer-reviewed open-access journal that focuses on general and internal medicine, pathogenesis, epidemiology, diagnosis, monitoring and treatment protocols. The journal is characterized by the rapid reporting of reviews, original research and clinical studies across all disease areas.

\section{Dovepress}

A key focus is the elucidation of disease processes and management protocols resulting in improved outcomes for the patient.The manuscript management system is completely online and includes a very quick and fair peer-review system. Visit http://www.dovepress.com/ testimonials.php to read real quotes from published authors.

Submit your manuscript here: http://www.dovepress.com/international-journal-of-general-medicine-journal 